
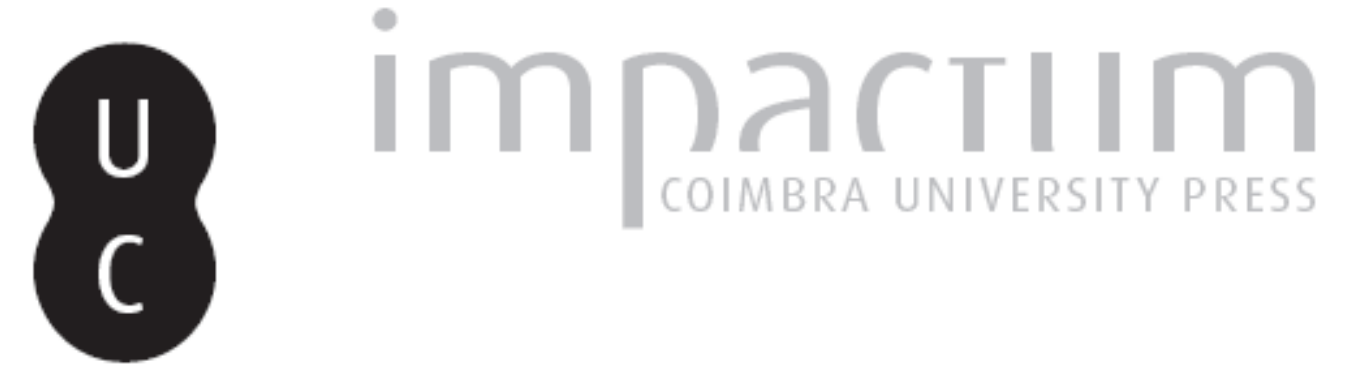

\title{
E. Levinas - J. Derrida: pensamentos da alteridade ab-soluta
}

\author{
Autor(es): Junges, Márcia; Bernardo, Fernanda
}
Publicado por: Faculdade de Letras da Universidade de Coimbra, Instituto de Estudos Filosóficos

URL persistente:

URI:http://hdl.handle.net/10316.2/29452

DOI:

DOI:http://dx.doi.org/10.14195/0872-0851_42_9

Accessed : $\quad$ 26-Apr-2023 09:09:18

A navegação consulta e descarregamento dos títulos inseridos nas Bibliotecas Digitais UC Digitalis, UC Pombalina e UC Impactum, pressupõem a aceitação plena e sem reservas dos Termos e Condições de Uso destas Bibliotecas Digitais, disponíveis em https://digitalis.uc.pt/pt-pt/termos.

Conforme exposto nos referidos Termos e Condições de Uso, o descarregamento de títulos de acesso restrito requer uma licença válida de autorização devendo o utilizador aceder ao(s) documento(s) a partir de um endereço de IP da instituição detentora da supramencionada licença.

Ao utilizador é apenas permitido o descarregamento para uso pessoal, pelo que o emprego do(s) título(s) descarregado(s) para outro fim, designadamente comercial, carece de autorização do respetivo autor ou editor da obra.

Na medida em que todas as obras da UC Digitalis se encontram protegidas pelo Código do Direito de Autor e Direitos Conexos e demais legislação aplicável, toda a cópia, parcial ou total, deste documento, nos casos em que é legalmente admitida, deverá conter ou fazer-se acompanhar por este aviso.

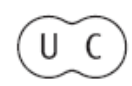




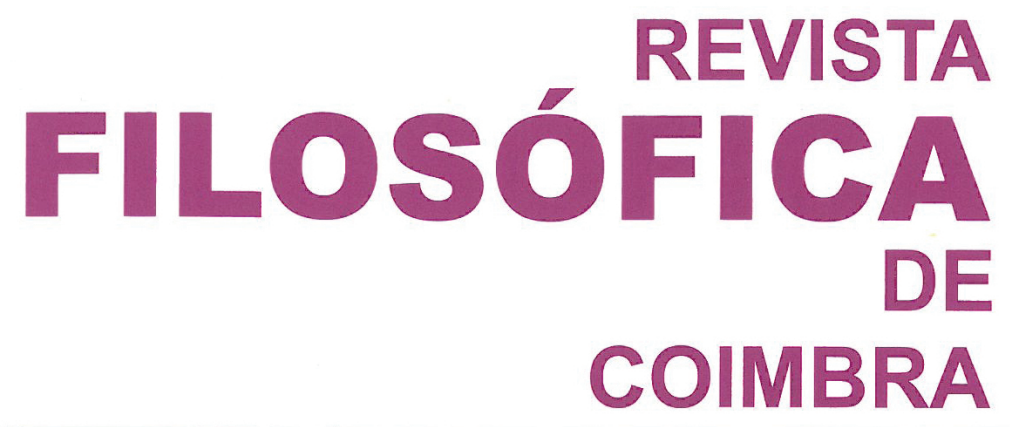

vol. 21 - número 42 - outubro 2012

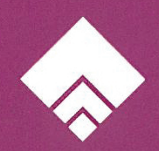




\title{
E. LEVINAS - J. DERRIDA: PENSAMENTOS DA ALTERIDADE AB-SOLUTA ${ }^{1}$
}

\author{
MÁRCIA JUNGES E FERNANDA BERNARDO
}

\begin{abstract}
«Ce qui vient au monde pour ne rien troubler ne mérite ni égard ni patience»

René Char
\end{abstract}

\begin{abstract}
Márcia Junges: Como Levinas influencia Derrida em sua filosofia da desconstrução?
\end{abstract}

Fernanda Bernardo: Pergunta imensa que pressupõe elou solicita um trabalho de investigação e de reflexão que, no essencial, está ainda por fazer e se apresenta como uma inadiável e formidável tarefa para o "futuro" - para o "futuro" e para o "futuro" da própria filosofia onde hoje reina um tão pesado silêncio...

Mas, em relação a estes dois nomes maiores da contemporaneidade filosófica, eu não falaria de "influência" - antes de singular herança [no sentido em que Derrida no-la dá a pensar, em Espectros de Marx, (1993) nomeadamente] e de proximidade electiva. Ambos os filósofos falam, aliás, do seu encontro filosófico como tendo sido da ordem do "prazer de um

${ }^{1}$ Entrevista conduzida por Márcia Junges a Fernanda Bernardo para um dossier dedicado a Emmanuel Levinas pela Revista IHU (Revista do Instituto Humanitas Unisinos, $\mathrm{n}^{\circ}$ 277, Ano VIII, 14.10.2008) - nesse dossier, onde colaboraram também J-F Mattéi, L.C. Susin, M. Cragnolini, P. Pivatto, R. Timm, R. Haddock-Lobo, S. Critchley, M. Pelizzoli e R. Bernasconi, foi então apenas publicada a primeira pergunta-resposta, em razão da sua extensão e com a intenção de editar posteriormente toda a entrevista num dos Cadernos Unisinos. Com a amável autorização de Márcia Junges, a quem muito agradecemos, publicamos agora aqui na íntegra, com ligeiras alterações, essa entrevista. 
contacto no coração de um quiasma": um "contacto tangencial" (passe a manifesta tautologia) entre dois idiomas ou entre duas grandes singularidades filosóficas que abre no entanto para um sem número de diferenças.

Antes, porém, de muito, de demasiado sucintamente tentar salientar e a proximidade e os diferendos deste "contacto tangencial", não deixarei de referir também ainda aqui que o próprio Derrida (em Janicaud, Heidegger en France I, $p$. 106) elege Heidegger, Levinas e Blanchot como os seus próximos eleitos. Próximos com os quais não cessou nunca de "dialogar" - e próximos (ainda assim, e como ele mesmo o disse, mais outros do que todo e qualquer outro) cuja admirável grandeza (de pensamento, de obra e de escrita), no meu entender, ele excede, excedendo em ousadia, em radicalidade, em finura, em inventividade e em justiça o rastro incandescente dos seus pensamentos.

O que é dizer que, abraçando o gesto daqueles próximos-eleitos no árduo exercício da sua "fidelidade a mais de um", Derrida nos dá de novo e diferentemente a repensar o "todo" da nossa ocidentalidade filosófico-cultural, na miríade das suas manifestações (religiosas, filosóficas, poético-literárias, éticas, políticas, jurídicas, ...), para além mesmo da sua memória judaico-greco-europeia - o seu próprio para além (mas ainda) nela fora dela, como o avesso do seu tecido ou a malha caida do seu tecido -, detectando nesse "todo" o indesvendável e profético-messiânico segredo da différance. Um segredo sem segredo - um segredo ab-soluto. Não sem justiça e não sem pertinência, de Derrida se poderá igualmente também dizer que o seu pensamento, dito "desconstrução", abalou a "paisagem sem paisagem do pensamento" desde que no mundo há pensamento e pensamento's do mundo: o próprio Levinas soube aliás reconhecer, já no início da década de 70 - quer dizer, quando se contavam ainda pelos dedos de uma só mão as obras editadas de Derrida -, que, com ele, com Jacques Derrida tudo era "tout autrement" (cf. Levinas, Nom Propres).

Dito isto, eu diria que a extra-ordinária proximidade (de pensamento) entre Derrida e Levinas se marca precisamente ao nivel da hiper-radicalidade ou da extra-vagância do seu pensamento e daquilo que os apelou a pensar elou lhes deu a pensar: a saber, o outro, o absolutamente outro (tout autre) tido como o limite, como um verdadeiro limite, um limite absoluto da filosofia na sua tessitura determinantemente ontológica. Tanto a meta-ética levinasiana como a desconstrução derridiana são, de facto, pensamentos da alteridade ab-soluta: pensamentos ditados, inspirados, magnetizados e afectados pelo "absolutamente outro" (o "separado" ou "santo", dirá Levinas na tradição do kaddoch hebraico, «não importa 
quem» («quiconque»), qualquer um/a, dirá Derrida, no segredo absoluto que o porta e o salvaguarda como outro).

Uma hiper-radicalidade que ambos os filósofos, notemo-lo também de passagem, herdam singularmente da fenomenologia husserliana - mais precisamente, da épokê husserliana. Uma épokê (redução) agora ocupada, já não, como acontecia em Husserl, com o delineamento da redução fenomenológico-transcendental e com os olhos postos na descoberta da apodicidade do "ego" constituinte aquém do mundo e aquém do ser; mas uma épokê agora exercitada naquilo que Emmanuel Levinas designará de redução inter-subjectiva, a qual, para além de testemunhar o quanto a singular primazia do "outro" chega demasiado tarde à fenomenologia husserliana - assim desvelando o seu registo autonómico ou egológico-egocrático -, dá também conta do facto de a sua inevitável chegada ditar pura e simplesmente a impossibilidade da própria fenomenologia transcendental ( $c f$. Lyotard e Alliez). Com efeito, o outro, que não por acaso Husserl designará de alter-ego, vem perturbar e impossibilitar o exercicio do princípio dos princípios (a intuição) sobre o qual a fenomenologia transcendental se alicerça.

No entanto, esta extra-ordinária proximidade de pensamento e quanto ao que os apelou e/ou lhes deu a pensar será também aquilo a partir do qual e em nome do qual Levinas e Derrida se separam. O que é dizer que esta singular proximidade de pensamento compreende (e singular proximidade porque é uma proximidade na diferença ou na separação, de acordo, aliás, com o sentido do filosofema "proximidade" em ambos os filósofos), da parte de Derrida, e a fidelidade e o diferendo. E a fidelidade e a resistência. A resistência e o diferendo na própria fidelidade e proximidade - apesar da proximidade e da fidelidade e em nome da proximidade e da fidelidade. Um diferendo ditado mesmo pela extra-ordinária fidelidade, na extra-ordinária fidelidade e em nome da extra-ordinária fidelidade ao pensamento audacioso do "absolutamente outro" de Levinas que, no dizer confesso de Derrida, o terá incondicionalmente obrigado (cf. "En ce moment même dans cette ouvrage me voici" in Psyché). Para vislumbrar e compreender neste diferendo a fidelidade da proximidade de Derrida a Levinas, pense-se apenas no que, na sua obra, Levinas diz da "Obra " - a saber, da relação ou do movimento para o outro [a própria "ética" ou a "justiça" para Levinas - de que "Obra" é um outro nome] que não retorna mais ao "eu-mesmo" e que, enquanto tal, exige uma infidelidade absoluta do outro - que, justamente, assim se queda outro, "separado" ou "santo", na terminologia reinventada de Levinas. No seu segredo ab-soluto, dirá Derrida, porque o outro é secreto, justamente, porque é outro. 
A fim de muito sumariamente tentar agora explicitar esta proximidade de pensamento entre Derrida e Levinas, lembremos muito sucintamente que, pensamento da différance, da vez, do evento ou da singularidade, Derrida também "define" a desconstrução [nomeadamente em "Psyché. Invention de l'autre" (in Psyché. Inventions de l'autre, p. 26-27)], como um pensamento ou como uma certa experiência do impossível: isto é, explicitará Derrida, do "outro", do "absolutamente outro" (tout autre), da invenção ou do porvir.

E lembrarei também ainda que todos os "incondicionais" ou "impossíveis" da desconstrução derridiana [a saber, o pensamento (que Derrida faz questão de singularmente distinguir de filosofia), o dom, a justiça, a tradução, o amor, a amizade, a democracia por vir, a decisão, a resposta, a responsabilidade, o testemunho, a hospitalidade, o perdão, o poema, a morte, a literatura, o sim, ...)] traduzem e testemunham a hiper-radicalidade deste pensamento do impossivel [um pensamento que tem implícito, notemo-lo também, um repensar da tradição do possível (dynamis, potentia, possibilitas) de Aristóteles a Heidegger, inclusive] e, na radicalidade da sua impossibilidade, encontram as irrespiráveis paragens da meta-ética levinasiana: dando assim conta do Dever absoluto diante do outro e para com o outro que magnetiza a hipérbole e a aporia do "pas au-delà" da desconstrução derridiana. Inversamente, este mesmo registo da incondicionalidade ou da impossibilidade não deixa também de salientar o registo hiper-ético da própria desconstrução (um registo marcado pelo recorrente e indecidivel "il faut") desde o primeiro passo do seu ousado, insistente e todavia vacilante "pas au-delà", assim atestando a inexistência de qualquer "viragem" ética ou política no pensamento e na obra de Derrida. Dele se poderá dizer (e é também uma diferença em relação a Levinas!) que o seu pensamento irrompeu logo como que inteiro - com efeito, dele não se poderá dizer que teve uma evolução, que se foi precisando no decurso do tempo e da obra, como acontece com o pensamento de Levinas. O que não pode deixar de surpreender... Com efeito, não há um primeiro e um segundo Derrida! O Derrida pensador da escrita não é diferente do Derrida que ousa confessar a sua "fé» num «deus por vir»... Um «deus por vir» que conjugaria a justiça ab-soluta com o direito ab-soluto com a força ab-soluta... Mas há o Emmanuel Levinas de Totalité et Infini (1961) e o Levinas de Autrement qu'être ou au-delà de l'essence (1974)...

Esta proximidade de pensamento entre Derrida e Levinas testemunha-se também ainda a dois níveis: por um lado, Derrida confessar-se-á capaz de subscrever tudo quanto Levinas disse a respeito da sua "ética": em Altérités, (1986), nomeadamente, o filósofo admitirá que, "diante de um pensamento como o de Levinas nunca tem qualquer objecção". 
Por outro lado, e do lado da "ética" levinasiana, Derrida (que "definirá" a desconstrução como um pensamento do impossível) declarará também que ela é impossível - que ela só é, de facto, possível como impossivel. Logo como im-possivel. E isto, não só para a subtrair ao empirismo e ao hegelianismo como, paradoxalmente, para, na pureza da sua incondicionalidade, ela não cair no risco da violência do egotismo narcisista, incapaz de discernir o bem do mal, o amor do ódio, a hospitalidade incondicional do fechamento egoisto-nacionalista (cf. Derrida, "Le mot d'accueil", p. 66).

Uma declaração de impossibilidade que, em vez de lhe decretar o dobre a finados, salientará antes, para além da sua hiper-radicalidade, o seu carácter irremediavelmente contraditório ou, antes, aporético - carácter que lhe afinará a ênfase do seu hiperbolismo e da sua exigência e a distanciará, não só do gesto hegeliano, como de todo e qualquer moralismo, o qual, como o próprio Levinas sublinhou, "tem má reputação". E uma declaração que a distanciará também ainda de um "levinasianismo" fácil e encantatório na litania da sua pregação do outro: da "abertura ao outro", do respeito e da responsabilidade fáceis pelo outro... Fáceis, isto é, ideológicos.

Notemos também que esta proximidade de pensamento se revela mesmo numa inaudita proximidade lexical ou terminológica: com efeito, na sua comum desconstrução do registo determinantemente ontológico (ou onto-teológico) da filosofia ocidental, ambos os filósofos recorrem, no decurso dos anos 60, ao quase-conceito de "trace" ("rastro"). Um recurso que, atestando embora a proximidade de pensamento entre os dois filósofos, atestará já também o muito que os separará na sua proximidade (uma proximidade enquanto pensamentos da alteridade e, enquanto tal, de desconstrutores da ontologia - que tem sempre um alcance político de indole totalitária...): é que, em Derrida, "trace" vai muito para além do registo ainda antropocêntrico que ele não deixa ainda de ter no seio do pensamento de Levinas. Com efeito, na sua desconstrução do "próprio" do homem e da axiomática metafísica da filosofia ocidental, "trace" concerne em Derrida diferencialmente todos os viventes e todas as relações do vivente ao não vivente - e não apenas, como acontece em Levinas, as relações humanas, somente humanas (o próximo, o semelhante, o irmão, o outro homem, ...) no rastro da transcendência.

E muito sumariamente referida a proximidade de pensamento entre Derrida e Levinas, salientemos muito sumariamente também agora os diferendos que nesta proximidade, apesar dela, se manifestam: diferendos que não deixam de marcar os limites e as insuficiências da "ética" de 
Levinas, sem dúvida uma das mais ousadas, exigentes e justas da nossa contemporaneidade. Diferendos que não deixarão também de revelar que, na loucura da sua hiper-radicalidade, a desconstrução derridiana vai ainda mais longe na sua vigília e na sua fome de "ética", de "justiça", de "responsabilidade" e de "desejo de invenção" do que a ética levinasiana, a quem marcará inauditos e surpreendentes limites: limites que, pelo essencial, revelarão o "carno-falogocentrismo" do "humanismo" profundo da "ética" levinasiana - uma ética assumidamente sacrificial.

Diferendos que, no essencial, provêm da resposta dada à questão: como bem pensar o outro e quem é "outro"? Quem é o "absolutamente outro" da ética levinasiana? Quem é o "absolutamente outro" que dita e locomove o pensamento destes dois filósofos? Questões que, para além de sublinharem o carácter ab-soluto do "outro", põem também em cena a difícil questão do "terceiro" (terstis, testis), outro do outro e outro outro. Questões a que, é sabido, Levinas responderá: o outro é "o outro homem". O "absolutamente outro" é "o outro homem": a saber, o outro como humano e o humano como homem. Derrida, por sua vez, responderá assim, assim respondendo à radicalidade do pensamento da alteridade de Levinas, que complexifica, ditando-lhe a im-possibilidade, isto é, o seu irremediável registo contraditório : "Tout autre est tout autre" "Absolutamente outro é absolutamente (todo e qualquer) outro".

"Tout autre est tout autre" é, de facto, a "pedrada" que o próprio Derrida diz ter atirado à ética levinasiana a quem, a par da inestimável grandeza, elevação e dificuldade, lembra a impossibilidade da sua pureza, assim problematizando, em primeiro lugar, o modo como Levinas deseja pensar a transcendência ou a exterioridade - a saber, de todo não contaminada pelo ser ou pela imanência. O sintagma que lança esta "pedrada", para além de concentrar, em toda a sua amplitude e aporeticidade, a "melancolia" do idioma derridiano (cf. Derrida, Carneiros Palimage), não deixa também de nos lembrar a sua intraduzibilidade - uma intraduzibilidade que metaforiza a do idioma ou a da própria alteridade ou singularidade absolutas -, e que nós "mal" traduzimos por "absolutamente outro é absolutamente (todo e qualquer) outro", a fim de tentarmos deixar quase ouvir a homonímia que, para além da tautologia, abre esta fórmula ao enunciado da heterologia mais irredutivel, lembrando-a à sua im-possibilidade - que o mesmo é dizer, lembrando o pensamento do "absolutamente outro" à inevitabilidade da contradição, da contaminação, da aporia ou do perjúrio quase-transcendental (cf. "Le mot d'accueil»). E, ipso facto, lembrando a "ética" ou a "justiça" ("a justiça para além da justiça”, precisemos, em razão do duplo sentido da "justiça" que atravessa o pensamento e a obra levinasianos) à inevitá- 
vel injustiça da sua justiça. Nunca um justo é pacifica e suficientemente justo... A tranquilidade da boa consciência do dever cumprido não está nunca ao seu alcance...

Para além de também significar o bem singular ateologismo da desconstrução derridiana ou (num sintomático dizer do filósofo que o aproxima do léxico e do pensamento levinasiano desejoso de pensar um Deus sem o ser, isto é, "transcendente até à ausência") o seu "ateísmo que se lembra de Deus" (um "ateísmo" que, note-se, é a condição para um muito exigente repensar da fé - de uma fé sem dogma nem religião, de uma fé pré-dogmática e adogmatizável - e, ipso facto, para um muito sério repensar, tanto da dita guerra das religiões, como do dito diálogo inter-religioso), este sintagma "Tout autre est tout autre" pretende lembrar a Levinas que, na sua unicidade de eleito, o "absolutamente outro" é "absolutamente todo e qualquer outro": não importa o quê ou quem (quiconque, n'importe qui, enfatizará Derrida, radicalizando a responsabilidade do pensamento diante de tudo e de todos), e não apenas o "outro homem", na sua condição de próximo, de semelhante ou de irmão, em cujo rosto "Deus", um "Deus transcendente até à ausência" nos vem à ideia, no consagrado dizer levinasiano. Um lembrar que revela o lugar do diferendo entre Derrida e Levinas. Mas, e insistimos, o lugar do diferendo a partir da proximidade e da fidelidade de Derrida ao pensamento de Levinas. Isto é, a partir da sua paixão comum pelo "absolutamente outro", que é, para ambos, aquilo que apela o pensamento a pensar - aquilo que dá a pensar.

Um diferendo introduzido com a difícil questão do terceiro (terstis, testis) [ao mesmo tempo prévio, interruptor e posterior ao face-a-face meta-ético] que se marca e se revela através de um sem número de diferenças entre os dois filósofos. Diferenças de entre as quais, num modo necessariamente telegráfico, lembrarei aqui as seguintes:

$1^{a}$ A questão da estratégia e da economia discursivas de Levinas: uma questão que se manifesta nomeadamente na frontalidade da oposição de Levinas ao registo privilegiadamente ontológico da filosofia ocidental, (ora, lembrará Derrida, já em 1963, em "Violence et Métaphysique", quando nos opomos, damos de antemão razão a Hegel!), e ao modo como o filósofo pensa a exterioridade ou o absoluto de uma alteridade que deseja não contaminada pelo ser - modo que ocorre sobretudo nos anos 60 e se manifesta muito especificamente em Totalité et Infini (1961).

À frontalidade e à rectidão levinasianas, contraporá Derrida a inevitável figura do oblíquo, do viés, do desvio (na rectidão (droiture), apesar da rectidão e mesmo em nome da rectidão), da destinerrância do envio, do "double bind", da contaminação e da aporia: figuras que salvaguardam 
a "ética" levinasiana, como um pensamento da alteridade respeitada, da argumentação hegeliana. E, em parte pelo menos, Levinas parece ter escutado as objecções de Derrida porque, em Autrement qu'être, dirá que o sujeito ético (tal como o filósofo e a filosofia!) é obrigado a viver na "contradição" (mas nunca na contaminação!), na "traição" e na "hipocrisia" pelo pouco de justiça de que, no mundo, tem a força de ser capaz.

$2^{a}$ A questão do humanismo (repensado, é certo, mas ainda assim um "humanismo) da "ética" levinasiana: "humanismo" que Derrida grafará "humainisme" a fim de nele denunciar a aliança do fonocentrismo e do logocentrismo através de um certo privilégio da mão, da mão do homem (humain) - de uma certa maneira ainda presente no pensamento levinasiano do "contacto" e da "carícia" - bem como da relação da mão à linguagem e ao pensamento. Lembremos de passagem que, embora crítico do velho "humanismo" que, no seu entender, não soube estar à altura do humano, a ética levinasiana se quer, no dizer de um dos títulos da obra do filósofo, um «Humanismo do Outro Homem» (do outro como humano - no esquecimento da sua responsabilidade pelo vivente animal - e do humano como homem - no esquecimento e na secundarização do "feminino", não obstante nos anos 40 tido pela figura sem figura do absolutamente outro e pelo êxtase do porvir e, nos anos 60, a ambiguidade de Totalité et Infini o ter também pelo "acolhedor por excelência»);

$3^{a}$ Em estrita conexão com a questão anterior, a questão dita do animal - "eu descrevo a ética", assume Levinas, ela "é o humano enquanto humano". Ora, se Levinas inverteu de facto a tendência ontológica da filosofia e do sujeito, cuja enigmática e vulnerável humanidade se plasmará e o plasmará como rosto (visage); se Levinas submeteu de facto o sujeito a uma radical heteronomia dissimétrica; se ele fez do sujeito um sujeito sujeito à lei da substituição; e se Levinas diz que o sujeito é antes de mais um "hóspede" (em Totalité et Infini) e um "refém" do absolutamente outro (em Autrement qu'être), verdade é, porém, que este "sujeito ético" é, antes de mais, um rosto humano e fraterno. Jamais o outro é, no pensamento de Levinas, um vivente animal. Que para este filósofo não tem rosto. Jamais o animal é, para Levinas, um rosto. Nem mesmo um terceiro!

Nestes termos, se para Levinas só há responsabilidade diante de um rosto, e se a responsabilidade atesta a incondição do sujeito ético ou humano, temos necessariamente de concluir que a humanidade do "sujeito ético" não se atesta nem se testemunha também na sua responsabilidade diante do animal - diante do sofrimento e do mal infligidos ao animal.

Eis a razão pela qual Derrida - o primeiro filósofo que se viu visto pelo animal e que não se limitou apenas a vê-lo, o filósofo para quem 
o "absolutamente outro é absolutamente todo e qualquer outro", não importa quem nem o quê -, detectará e mostrará como o "falogocentrismo" do humanismo levinasiano se agrava num inquietante "carno-falogocentrismo", isto é, numa indiferença ao sacrifício do vivente animal - em manifesta contradição com o princípio de vida (torat haïm) defendido pelo judaísmo ("Não matarás»é, para Levinas, o mandamento dos mmandamentos...). Um princípio intangível que, como Derrida refere, nunca impediu o sacrifício animal no judaísmo... Pensemos no «carneiro» que, no Sacrifício de Abraão, substituiu Isaac...

$O$ dito animal - o animal antes de nós, diante de nós e, em nós, fora de nós (cf. J. Derrida, L'animal que donc je suis), é pois um grande esquecido da ética levinasiana. Um estranho esquecimento da parte de uma ética dissimetricamente heteronómica que, ainda por cima, diz dever assumir incondicionalmente a sua obrigação diante do "primeiro vindo" - ora, no dizer do Génesis, o animal, no qual Derrida vê uma figura da alteridade absoluta - mais outra do que a do semelhante, do próximo ou do irmão -, terá sido criado e terá chegado ao mundo primeiro do que o homem. Que deveria assim também responder responsavelmente diante dele e por ele - que, como J. Bentham lembrou, no seu imenso impoder tem no entanto, como o humano, o poder de sofrer ("can they suffer?»).

$4^{a}$ A questão do "feminino" e das "diferenças sexuais": não sem deixar de saudar a coragem e o mérito insigne de Levinas por este ter assumido a masculinidade da sua assinatura filosófica - coisa que (apesar da ambiguidade que consigna, uma vez que implica um posicionamento na própria diferença sexual, que assim se vê rasurada e/ou economizada) é, como muito bem sabemos, raríssima em filosofia! - bem como pelo seu empenho na temática fenomenológica de eros e do feminino [cf. Levinas, De l'Existence à l'Existant; Le Temps et l'Autre, Totalité et Infini], Derrida denuncia no pensamento e na obra de Levinas a violência de uma certa dissimetria falocêntrica. Um falocentrismo ou um androcentrismo marcados, por exemplo, no privilégio do Il e da Illéité na designação do "tout autre"; no privilégio do Pai e do Filho na sua alusão à filiação (cf. Totalité et Infini); na sua distinção entre rosto feminino (equacionado ao Tu de Buber) e rosto magistral (equacionado ao Vós - altura, magistralidade, vulnerabilidade, imperatividade e resistência éticas) (cf. Totalité et Infini); numa certa alusão à Amada, à feminilidade da Amada estranhamente associada, em Totalité et Infini, à infância, à irresponsabilidade, à coquetterie e à animalidade,... Um privilégio que, reatando com a poderosíssima tradição abraâmica, é indissociável do privilégio da fraternidade na ética levinasiana. Um privilégio a ser devidamente repensado, dado o seu liame à genealogia familiar e ao sangue.

Por outro lado, numa extraordinária atenção à textura do texto 
levinasiano, Derrida não deixará de saudar também (é, aliás, o único a fazê-lo!) a possibilidade de pensar o "feminino" em Levinas no sentido de um certo "femininismo avant la lettre" - quer dizer, e como Derrida no-lo dá a pensar, prévio à própria "diferença sexual". Uma leitura que o filósofo nos dá em "Le mot d'accueil» a partir da sua leitura do "feminino" em Totalité et Infini (D. La demeure) pensado como "acolhimento por excelência", como "linguagem silenciosa" ou como "expressão no segredo". Uma leitura no entanto só compreensivel a partir dos pressupostos do pensamento derridiano da arqui-escrita.

$5^{a}$ A questão do perdão: o perdão em Levinas implica sempre arrependimento e, consequentemente, a sua solicitação. Diferentemente, para Derrida o perdão é «uma loucura do impossivel» - modo de dizer que um perdão que merece o nome é sem condições (cf. Derrida, "Le siècle et le pardon»);

$6^{a}$ A questão do judaísmo: Apesar do repensar ético (ou categorial) do judaísmo por Levinas (para quem Deus, "transcendente até à ausência", vem à ideia na relação inter-humana, ou seja, para quem a relação a Deus é inconcebivel fora da relação ética com os homens), as diferenças entre Derrida e Levinas, a este nível, são mais do que muitas e passam sobretudo pela sua diferente concepção da importante noção de "eleição" (cf. Derrida, "Abraham, l'autre»): não sendo nenhum privilégio, mais ou menos folclórico, nem nenhum particularismo rácico ou cultural, mas uma eleição pela responsabilidade e para a responsabilidade infinita e universal, um certo «exemplarismo judaico» não está de todo ausente do pensamento levinasiano da "eleição" [nem da poética de Celan!] para quem o "judeu” é, por excelência, a figura do humano verdadeiramente ou justamente humano. Fragilizando e indeterminando a «eleição», Derrida desconstrói a ideia de "pertença», de "comunidade», de "propriedade», de «identidade una», etc.

Dai que, se é certo que, ao repensar eticamente o judaísmo, foi desejo de Levinas traduzir na linguagem (grega) da filosofia a mensagem (privilegiadamente judaica) de uma espiritualidade ou de uma humanidade rebelde às formas do saber, Derrida irá ainda mais longe - na verdade, lembrando que "Jewgreek is greekjew. Extremes meet", ele vai mesmo para além e do "judaísmo" (não sem ironia, diz-se aliás o último elou o primeiro dos judeus ou um "marrano universal») e do "helenismo", mostrando como eles próprios, na sua pretensa unidade una, se auto-desconstróiem e se contaminam, e como todos o's pensamento's do mundo (como, no fundo, eles mesmos são) são já sempre uma tradução de tradução do intraduzível. Provimos de «mais de uma tradição» - para dizer esta duplicidade da origem, como a própria «origem», e na origem, Derrida recorre a dois nomes históricos: "khôra» (a do Timeu de Platão) e «messiânico». 
$7^{a}$ A questão do messianismo e do político: do muito que haveria a dizer sobre estas questões imensas, referirei aqui apenas que Derrida repensa o messianismo levinasiano em termos de messianicidade - que o filósofo traduzirá em Spectres de Marx, na sua leitura de Marx, no tempo da "nova Internacional" por vir: uma internacionalidade que terá a sua novidade, o seu motor e o seu porvir no espírito de justiça (pensada como acolhimento incondicional do outro na sua singularidade prévia à sua cidadania), o imperecivel espírito do marxismo, tanto para Derrida como para Levinas. Uma messianicidade que, para além de assumir uma total proximidade a Levinas em questões como as da hospitalidade incondicional ou de visitação, das cidade-refúgio e do "político depois!" [questões que, por si mesmas, são o gérmen para um repensar revolucionário do político, da democracia, da própria ideia de revolução e do direito (nacional e internacional)], um abismo o separa de facto da cultura e da praxis política do filósofo da ética como prima philosophia. No entanto, apesar destas diferenças, importa notar que ambos os filósofos são sem álibis em relação a Israel, fazendo Derrida seu o veredicto de Levinas que diz ter como uma verdadeira lição de política, em Israel, na Palestina ou seja lá onde for: "A pessoa é mais santa do que uma terra, mesmo quando é uma terra santa, porque diante de uma ofensa feita a uma pessoa, esta terra santa aparece, na sua nudez, como um amontoado de pedras e lenha.»

M.J.: Derrida disse que Levinas abalou a "paisagem sem paisagem do pensamento". É possível afirmar que a sua filosofia é um divisor de águas no pensamento contemporâneo? Porquê?

F.B.: Sim, sem dúvida, e não sem justiça. E não apenas no pensamento contemporâneo. É que, inspirado e magnetizado pelo absolutamente outro [tout autre] para além do ser ou diferentemente do ser, o pensamento de Levinas não é apenas "um divisor de águas" no seio da contemporaneidade filosófica: mais lata, mais justa e mais precisamente, o seu pensamento é "um divisor de águas" no âmbito de toda a ocidentalidade filosófica, cuja violência sibilinamente denuncia ["esse est interesse!", proclama Autrement qu'être, $p$. 4] ao denunciar a sua reverência à ontologia, o privilégio que outorga ao teoretismo e a sua concepção do próprio psiquismo em termos de saber.

Lembro que, para além de Derrida, também Maurice Blanchot (in "Connaissance de l'inconnu" em L'Entretien infini, Gallimard, Paris, $1969, p$. 74, nomeadamente) viu e admirativamente saudou no pensamento 
levinasiano "um novo ponto de partida para a filosofia": o da alteridade ab-soluta (isto é, separada, noto, e não plena ou total) do outro. Esta extraordinária atenção à alteridade ab-soluta, isto é, nunca apropriada nem dialectizada nem sequer mesmo compreendida, mas justa e efectivamente salva-guardada e respeitada no absoluto da sua alteridade, é a grande originalidade e o grande legado de Levinas: a viragem meta-ética da filosofia tem o seu idioma e a sua assinatura. Com ele, a "ética" não é mais uma disciplina do corpus filosófico, nem tão pouco um conjunto de regras norteadoras da acção, mas a "filosofia primeira»: aquela que pensa "o humano enquanto humano». Um humano que, na linha de um certo Platão, está sempre acima do homem.

Com efeito, excepção feita a algumas fulgurações pontuais [assinaladas pelo próprio Levinas: o Bem para além do ser (epekeina tes ousias) e o Uno sem o ser da $1^{a}$ hipótese do Parménides de Platão, o intelecto agente de Aristóteles, a ideia de infinito no finito de Descartes, o primado kantiano da razão prática, a épokê husserliana, o super-homem de Nietzsche, ...], a filosofia ocidental - a filosofia que nos é transmitida, no reiterado dizer de Levinas - revelou-se, desde o Poema de Parménides até à Fundamentalontologie ou ontologia hermenêutica de Heidegger, uma filosofia determinantemente alérgica ou indiferente ao "outro", que sempre apropriou, reduzindo-o ao "mesmo", através de modalidades diversas da mediação. Modalidades que vão da apropriação à compreensão. Substituindo a mediação pela interrupção ininterrupta [separação/substituição - marcas da singular arqui-originariedade do "outro" como outro ou secreto e do "ateísmo" ou da "religiosidade" do "sujeito ético"], Levinas marcou a filosofia, toda a filosofia com o selo da heteronomia. É o seu selo - a sua marca. A sua assinatura. E, na sua excepcionalidade, não menos que na ambiguidade da sua irredutivel contradição, uma tal marca é um repensar exigentemente inventivo da filosofia - não mais tida como "amor da sabedoria", mas como "sabedoria do amor ao serviço do amor» pelo outro para com o outro ( $c f$. Autrement qu'être, $p$. 207). A meta-ética levinasiana tem um recorte antropocêntrico.

Por outras palavras, uma tal marca é um repensar "ético" (no sentido de meta-ético) dos fundamentos tradicionalmente ontológicos ou mesmo onto-teológicos da filosofia (da moral, da política, da justiça, da subjectividade, da racionalidade, ...). E a este nivel, e para além do idioma derridiano - ele ainda mais desconhecido, maltratado e rejeitado -, Levinas continua ainda a ser - para além também de um "levinasianismo" piedosamente dormente na sua litania gasta, desgastante e agastante do outro -, uma voz de excepção no panorama filosófico contemporâneo. De excepção e de rara exigência para um muito urgente repensar do crescente deserto de humanidade e de responsabilidade do nosso "hoje" em 
tão pobre, insuficiente e arriscada mundialização - «Vivemos sob céus sombrios e... existem poucos seres humanos.», Celan dixit.

M.J.: Levinas definiu a morte como a paciência do tempo. Que elementos esse autor traz para pensarmos a morte do ponto de vista de quem morre e do ponto de vista de quem fica?

F.B.: Ainda no eco da sua pergunta anterior, e em jeito e de justificação e de exemplificação da minha resposta, direi, para começar, que, contra o todo da filosofia ocidental, de Platão a Heidegger, inclusive, Levinas vai repensar a morte não mais a partir do ser (ou do não ser) - to be or not to be não é mais a questão última, proclamará reiteradamente o filósofo! -, mas a partir da morte e do morrer do "outro homem" como um limite absoluto ao poder de poder da subjectividade e da racionalidade interessadas ou, na terminologia de Totalité et Infini, onto-auto/ leco-nómicas, quer dizer, soberanas: o evento misterioso e traumático da morte não põe apenas em questão o direito a ser, pondo a nu o absurdo e o fim da suposta auto-suficiência do Mesmo, do conatus essendi, onde determinantemente o logos ocidental viu a figura última do livre e do racional (pense-se, a título de exemplo, na morte de Sócrates no Fédon (117e-118 a) de Platão! Pense-se também no zoon logon ekhon (animal racional, animal que tem o PODER do logos) de Aristóteles). A experiência (traumática, isto é, sofrida, dissimetricamente sofrida) da morte do outro - a única morte de que se morre! - revela o destino ou a incondição de sobrevivente meta-eticamente enlutado que é, no fundo, a de todo o vivente humano. $O$ que é dizer que a experiência da morte (que é, no fundo, a experiência do luto!) é não só a experiência da própria alteridade absoluta - da morte não há saber! A morte é um absoluto ponto de interrogação! - como a experiência da "individuação", da "sujeição" ou da "identificação" meta-éticas do "eu”. É que para Levinas, tal como para Derrida, a experiência do luto não ocorre apenas aquando da morte de alguém. Não. A experiência da morte apenas hiperboliza, pondo a nu, o que começa na mais abissal matinalidade da relação ao outro como outro, isto é, como mortal, vivo ou morto, e, ipso facto, na relação do próprio "eu" a si mesmo como outro. E dizemos ipso facto, porque a experiência do luto (impossivel e infinito) pelo outro põe a nu o luto originário do próprio "eu ético" - que por isso, vivente que é, não passa afinal de um sobrevivente. Este é um entendimento possivel da morte tida como «paciência do tempo» - o entendimento de que viver é, para um sujeito criado ou mortal, sobreviver: viver a morrer... Para o sujeito criado, como para o «literato» ou «escritor»- escrever é postumar: postu(a)mar: 
amar o póstumo, isto é, o que resta do que não resta mais... A escrita é uma singular actividade de despossessão-des-apropriação. Porque, para Levinas, como para Blanchot, como para Derrida, as palavras estão no lugar, e de quem escreve, e do que escrevem...

Com efeito, em Levinas, a morte não revela mais o cuidado preocupado consigo de um Dasein ou de um Sein-zum-Tode, como acontece em Heidegger: ela revela antes aquilo que o filósofo designa de sujeito-para-outrem. Um sujeito deposto da sua pseudo soberania e des-inter- essadamente ex-posto e pre-ocupado com a vulnerabilidade apelativa do outro, testemunhada na experiência-limite da sua morte. No seu intenso e intensamente agónico diálogo com Heidegger - o mestre muito admirado mas, em razão da sua proximidade ao nacional-socialismo, não amado -, Levinas vai, de facto, pensar a morte, subtraída ao horizonte do ser, a partir do morrer e da morte do outro e, portanto, a partir "do ponto de vista de quem morre" pensado em termos de uma alteridade absoluta: a morte, defenderá o filósofo, não é fim e nada, mas um puro enigma. Um absoluto ponto de interrogação. Ela não é, como pretendeu Heidegger, a derradeira "possibilidade da impossibilidade», mas a «impossibilidade da possibilidade». Quer dizer, o fim do poder de poder do sujeito interessado ou autonómico ou egológico, numa palavra, pretensamente soberano, e a descoberta da sua arqui-passividade enlutada e, portanto, incondicionalmente endividada e obrigada ao outro antes mesmo de ser. E em vez de ser. Luto originário e substituição (ou hetero-auto-afecção) andam de mãos dadas.

E tal é o sentido, digamos que positivo, do "sem sentido" da morte. No seu absurdo, a morte não deixa ainda assim de ter uma "significação" para Levinas. Uma "significação" que se manifesta justamente "do ponto de vista de quem fica", ou seja, que se manifesta do lado do sobrevivente enlutado e para o sobrevivente que, na (hetero-)afecção provocada pelo morrer do outro, isto é, no seu luto pelo outro, descobre, a par do fardo da sua inexorável mortalidade, a sua incondição de sobrevivente ética ou arqui-originariamente (i.e. antes de ser) enlutado e, ipso facto, de incondicionalmente obrigado ou votado ao outro. Obrigado a carregar, obrigado a bem portar o outro como outro - isto é, em si (mas) fora de si. Razão pela qual Levinas dirá que a experiência da morte descobre "a vocação humana do des-inter-essamento."

M.J.: A culpabilidade do sobrevivente e sua infinita responsabilidade, além de fundantes de um respeito pela alteridade, não seriam também exigências grandes demais ao ser humano, para as quais não estamos preparados? 
F.B.: Em jeito de resposta, permito-me perguntar: não é o próprio Levinas que, na assumida pengada de um certo Platão, diz que o "humano está talvez [sempre] acima do homem"? E não é também ainda Levinas que, em vez de falar da essência, da natureza, do próprio ou mesmo da condição do humano, fala justamente da sua "incondição" para nos dar a significar a ineliminável passividade arqui-originária do "humano", por isso incondicional, infinita e arqui-originariamente obrigado ou responsabilizado (antes mesmo de ser e diferentemente de ser) diante da altura, da vulnerabilidade, da enigmaticidade e da resistência apelativas do rosto do "outro homem" que, "primeiro vindo", detém a primazia? E não é esta a condição, quer para a in-finita (isto é, infinitamente finita) responsabilidade que deveria definir o «eu», quer para evitar o moralismo? O moralismo ideológico ou filosófico-normativo - o da «boa consciência» do dever cumprido... Esta culpabilidade originária (nasce-se culpado, isto é, acusado, isto é, a responder - isto é, sujeito!) é, porém, sem falta.

E não é também ainda Levinas o filósofo que confessou nunca ter pretendido descrever a realidade humana tal como ela é, mas sim aquilo que a própria depravação humana, no fundo, não é capaz nem de ignorar nem de negar? A saber, aquilo que o filósofo designa de "vocação humana para a santidade", isto é, para o reconhecimento da singular primazia do "absolutamente outro". Aquilo a que o filósofo (in Altérité et transcendance), na sua impressionada leitura de "Vie et Destin» de V. Grossman, há-de chamar a "pequena bondade": uma "bondade" no entanto alheia a qualquer sistema, a qualquer normatividade, a qualquer religião, a qualquer ética, a qualquer organização social e mesmo a qualquer generosidade altruista. Uma "bondade" não instituida nem instituivel. Uma bondade que é o remorso de toda e qualquer bondade - pessoal ou instituída em misericórdia 's. E portanto o apelo à sua perfectibilidade. Uma bondade que não passa afinal daquilo a que, muito significativamente, o filósofo há-de chamar a "extra-vagância" da responsabilidade infinita pelo outro e para o outro como a incondição de um "humano", se não finalmente à altura, pelo menos a caminho do próprio "humano". Não, nunca se chegará a Córdova (F. Garcia-Lorca)...

Observo ainda que, na sua desmesura, a hybris desta responsabilidade do sobrevivente (uma desmesura que corresponde, noto-o, à hiper-radicalidade ou à hiperbolicidade deste pensamento da alteridade, traduzindo no fundo o registo meta- (ou hiper-) da (meta)ética levinasiana: uma "ética" meta-ontológica e meta-gnosiológica) é absolutamente fundamental a fim de a afastar, tanto de uma melopeia moralizante que imporia valores à consciência e à razão (consciência e razão que, repensadas, têm agora a sua origem na "extra-vagância desta generosidade do para-o-outro"), como de uma sabedoria humanista fundada num psiquismo 
altruista, generoso e tolerante. À semelhança de Derrida, também Levinas não se cansará de chamar a nossa atenção para a obscenidade egoísta e para a intolerância da tolerância!

Importa-me também ainda sublinhar que esta questão da "culpabilidade", da "culpabilidade sem falta" do sobrevivente (que, de uma certa maneira, também ecoa na Schuldigsein de Heidegger - como, no fundo, ecoa em todas as filosofias que pensam o sujeito em termos de relação) não se coloca e não ocorre apenas diante da morte de outrem, isto é, no momento da sua morte, mas diante da mortalidade irremediavelmente inscrita no seu rosto (e que o seu rosto, como rosto da alteridade, justamente, exprime (kath'auto)): o que é dizer que uma tal culpabilidade é uma experiência originária e originariamente desconstrutiva do "humano ético" ou des-inter-essado, isto é, que não se pensa mais em termos autonómicos ou ipsocráticos na linha do distante hypokeimenon aristotélico. Ela revela muito simplesmente a cena da experiência da convocação dissimétrica de um sujeito "criado", "separado" ou "ateu" (em sentido levinasiano) pelo outro, e que portanto não se pensa mais a partir de si, a partir do seu umbigo, em termos de poder, mas antes de singular "impoder".

Nestes termos, saibamo-lo nós, ou não, queiramo-lo nós, ou não, pratiquemo-lo nós, ou não, esta responsabilidade infinita assedia-nos - é a incondição (incondição, quer dizer, não passível de ser assumida) do vivente humano - do sobrevivente enlutado que é, no fundo, todo o vivente humano. Uma incondição que significa também que nunca estamos, de facto, nem preparados para ela nem à sua altura - ela é uma disponibilidade permanente, uma exigência de toda a hora, um desejo infinito, um espinho dolorosamente cravado na alma do justo ou do humano responsável... Modo de dizer que ela é uma promessa (sem garantia, para merecer o nome de promessa) e uma exigência sobre-humana para um "humano" finalmente digno de chamar-se "humano". Derrida-que diz que só se faz mesmo alguma coisa quando se faz o impossivel, de contrário executa-se maquinalmente um programa previamente determinado, e nada de novo ou de diferente (nos) acontece - lembra-nos que, os degraus da escada desta tão exigente "elevação" solicitada pela ética levinasiana ao "humano" digno do seu nome, se elevam à medida em que ele os sobe... Mas é verdade que há alguns humanos mais vocacionados para esta responsabilidade do que outros - como é verdade que a crise dos nossos dias passa pela sua trágica ausência em todas as instâncias...

M.J.: Poderia comentar a duplicidade de sentido do "a-Deus" ao qual se refere Derrida em seu discurso no falecimento de Levinas? 
F.B.: Pergunta muito difícil. Para tentar um tal comentário, como me pede, começarei por escutar o ressoar desta palavra de singular saudação ("à-Dieu”) no próprio idioma de Levinas e de Derrida. Uma palavra que, em si mesma, notemo-lo, é mais de uma - "mais de uma", "mais de uma língua" é aliás também uma outra das definições da desconstrução (cf. Derrida, Mémoires - pour Paul de Man).

E lembrarei que, vindo do latino "ad", o primeiro elemento da palavra ("à-) significa, por um lado, "intencionalidade", "direcção", "orientação", "sentido", "movimento para", "abertura a”, ... "À-Dieu”" escutar-se-ia assim como "a Deus" ou "para Deus". Como "abertura" ou "movimento para Deus" ou "em direcção a Deus". Por outro lado, o mesmo "à-" significa igualmente pertença e dativo: "À-Dieu”, neste outro sentido, escutar-se-ia como "de Deus".

E lembrarei também ainda que, em Donner la mort (1999), o próprio Derrida nos lembra que a palavra "adeus" pode significar pelo menos três coisas: $1^{a}$ ) A saudação ou a bênção dada a outrem no momento do encontro; $2^{a}$ ) A saudação ou a bênção dada a outrem no momento da despedida - eventualmente uma despedida para sempre, na hora da morte, por exemplo; $3^{a}$ ) O A-Deus/Para-Deus/De-Deus, o de Deus, o para Deus ou o diante de Deus antes de qualquer relação ao outro e em cada relação ao outro - em cada "adeus", portanto. Lembrarei que Levinas diz que o céu está vazio, mas que a misericórdia de um ser humano por outro está cheiinha de "Deus»-ou seja, que «Deus» não está no céu, mas no sacrifício e na responsabilidade dos homens uns pelos outros...

E lembrarei finalmente também ainda que Derrida faz questão de nos dizer/ensinar que, tão ou mais importante do que aquilo que se diz, é o modo como se o diz - o que está relacionado com o célebre estilo derridiano, onde muitos, enfeudados a uma concepção ontológico-teorética da filosofia, não conseguem vislumbrar mais do que um simples estetismoou um gosto excessivo pelas nuances retóricas, na melhor das hipóteses. Uma irritante tendência para um desbragado narcisismo, na pior das hipóteses. E, naqueles que, à sua maneira e à sua medida, escutam Derrida, esses são, por norma e por não-saber, acusados de mimetismo... Acontece que um pensamento da (impossivel-necessária) singularidade, como o de Derrida, que se pretende singularmente pré-linguajeiro, pré-performativo e pré-teórico, tem necessariamente de cultivar um certo estilo e de dar a ouvir um certo tom: o estilo do endereçamento singular (numa situação singular e a uma dada singularidade) e o tom da melancolia [correspondente à destinerrância, à interrupção ou ao desvio da rectidão do endereçamento singular a um/a outro - a "relação sem relação" de Blanchot correspondente à própria "relação ética" de Levinas -, uma vez tal endereçamento proferido em voz alta, diante de outro's, na língua de outro's 
(paradigma por excelência da universalidade/da generalidade/da tercialidade) e para outro's também, portanto]. O que, observe-se também, tem como contraponto a distinção/imbricação do Dizer e do Dito de Levinas. $O$ que se poderá traduzir ainda dizendo que um tal pensamento se vive a cada instante: não é um mero saber encerrado num livro ou numa biblioteca a debitar no estilo da mera erudição, mas algo que, a cada instante, se vive e se pratica antes do encadear discursivo ou linguajeiro - o que é também dizer que, antes da dicotomia teoria-praxis, é um pensamento imediata e singularmente praxístico - performativo. Faz já o que diz.

Eis, para começar, o que no meu entender dá a significar a admirável cena final do tocante Adieu de Derrida a Emmanuel Levinas que me pede que comente. E que é também - como não o referir igualmente? - a cena do testemunho de admirável fidelidade de Derrida - na sua confessada grata condição de discípulo -, diante de "Levinas" morto: o Mestre amado e admirado (cf. Derrida, Adieu, $p$. 26). O testemunho de um discípulo que testemunha também, diante do Mestre que já não o ouve nem lhe responde mais - e é bem a condição da alteridade! -, o quão bem aprendeu o seu ensinamento. Quer dizer, não o lembrando apenas, a um tal ensinamento, mas vivendo-o e experienciando-o diante do Mestre e para o Mestre. Lembrando e experimentando que a experiência da morte ou do luto atesta, e por excelência, tanto a cena da "ética", da própria relação ético-metafísica ao outro como outro, isto é, na sua condição de silenciosa e secreta alteridade, passe a manifesta tautologia, como a cena da incondição ética do vivente humano segundo Levinas - a sua incondição de sobrevivente infinitamente enlutado e, portanto, infinitamente obrigado a bem portar o outro "em si fora de si". "Em si fora de si" como no fundo se porta sempre o outro como outro, quer dizer, na sua condição de separado. E, aliás, esta separação que se dá a escutar no "adeus" de Derrida a Levinas. Um "adeus" de saudação na separação (na separação de todas as separações, como é a ditada pela morte) que saúda o outro/Levinas no absoluto da sua singularidade ou da sua silenciosa enigmaticidade (para além do ser, portanto, e como uma singular excepção ao ser): como Derrida começa por dizer (cf. p. 11), "a quem é que nos endereçamos num tal momento?" Eu sublinho.

$E$ eis então, muito sumariamente necessariamente, a insinuação do que diz ser a "duplicidade de sentido do a-Deus" - ela configura a cena daquilo a que Levinas chamará "ateísmo". Uma cena que, por um lado, nos lembra que, para Levinas - que muito explicitamente assumiu querer pensar um "Deus sem o ser" "transcendente até à ausência" ou até à sua possivel confusão com o que designa de "il y a" -, Deus é sinónimo de "separação absoluta": o filósofo designá-lo-á também "o santo dos 
santos": o separado dos separados. O absolumente outro que, não raro, Levinas grafa com maiúscula.

Com efeito, haverá que lembrar aqui de passagem que o Deus de Levinas não é o Deus dos filósofos - o Deus da onto-teologia. Nem o Deus da teologia, das religiões positivas ou da mística: "[...] outro diferente de outrem, outro diferentemente, outro de alteridade prévia à alteridade de outrem" no dizer levinasiano de De Dieu qui vient à l'idée, (p. 115), Deus é para Levinas o "separado" ou o "santo" que, enquanto tal, nos lembra e nos apela à própria "santidade" do "outro homem" que está sempre mais próximo de Deus do que o «eu»: a saber, ao reconhecimento e da sua primazia e da sua separação. Ao reconhecimento da sua primazia espectral ou enigmática (e é o justo sentido da heteronomia levinasiana: o outro dissimetricamente privilegiado não é um outro soberano, mas um enigma ou um rosto).

E tal é também o "ateísmo" repensado por Levinas: sinónimo de "separação" [um "conceito" fundamental da ética levinasiana], o "ateísmo" significa que "a relação sem relação" a Deus (e uma "relação sem relação" porque se trata de uma relação com o ab-solutamente ausente ou outro sem mediação) tem lugar, não na crença religiosa, não no "eu creio [ou não creio] em Deus", mas sim na "ética". Na "ética" entendida, como Levinas a entende, como "relação ao outro", ao "ab-solutamente outro" ou rosto no rastro (trace) e como rastro da própria "relação sem relação" a Deus. Na "ética" entendida, em suma, como "adeus". Um "adeus" ao outro como outro, "em si" (mas) "fora de si", que é também um "adeus" ao próprio de si próprio. E isto porque um tal "adeus" também separa aquele que diz "adeus" de si próprio: do próprio de si próprio: uma separação que é o abismo onde se abre a sua responsabilidade pelo outro e para o outro - não menos que o abismo de onde brota a insondabililidade, tão irreprimível quanto desesperada, de uma outra "fé" (sem dogma nem religião) - em Deus ou no outro: num como no outro... Em suma, «somos três quando somos dois»-mas esta tercialidade nada tem que ver com a tercialidade do terceiro (testis, terstis), com a qual surge a questão e, portanto, a justiça como direito, a comparação, o cálculo, etc. Numa palavra, com a qual surge o aparecer ou a fenomenalidade em geral. Mas um aparecer ou uma fenomenalidade ditada ou inspirada e, portanto, interrompida ou heterogeneizada pelo outro, que é o "primeiro vindo» absoluto. Estoutra tercialidade é única e mais originária - designa o rastro de Deus a quem originariamente se responde em toda e qualquer resposta. Levinas também a designa, em Autrement qu'être, por illeité (eleidade). É também ele que faz à partida do outro um Vós - é nele que Deus vem à ideia. Em suma, o céu está vazio mas vivo na relação de aproximação de singularidade a singularidade... 
M.J.: Que obras de Levinas destacaria como fundamentais para compreender seu pensamento?

F.B.: Fundamentais, absolutamente fundamentais, no meu entender, são Totalité et Infini (M. Nijhoff, 1961), Humanisme de l'Autre Homme (Fata Morgana, 1972), Autrement qu'être ou au-delà de l'essence (M. Nijhoff, 1974) - obra onde a maturidade do pensamento de Levinas se expõe -, e De Dieu qui vient à l'idée (1982).

M.J.: E qual obra poderia ser indicada como uma introdução às suas ideias, devendo ser lida primeiro?

F.B.: Não sem hesitar, inclinar-me-ia para Éthique et Infini (1982), para Emmanuel Levinas. Qui êtes-vous? (1987) (um diálogo com François Poirié sobre o percurso da sua vida, do seu pensamento e da sua obra), para "Signature" (no dizer do próprio filósofo "um inventário avulso que é uma biografia") e, finalmente, para Dieu, la mort et le temps, obra que, porque reúne os dois últimos cursos professados por Levinas na Sorbonne durante o ano académico de 1975-76, constitui uma exigente e excelente introdução ao pensamento do filósofo, cuja dificuldade este formato (de cursos) ilumina e dissipa um pouco. 